\title{
Financing Devolution in a COVID-19 Environment: The Status of Devolution in Zimbabwe
}

\author{
Ruvarashe Chigiya-Mujeni $\odot$
}

$\mathrm{PhD}$. Scholar, College of Business, Peace, Leadership, and Governance, Africa University

* Corresponding Author (ruvamujeni@gmail.com)

Received: 14 April, 2021

Revised: 14 October, 2021

Accepted: 22 November, 2021

Published: 25 December, 2021

How to cite this paper:

Chigiya-Mujeni, R. (2021).

Financing devolution in a

COVID-19 environment. The status of devolution in Zimbabwe. Quest Journal of Management and Social Sciences, 3(2), pp. 307-322.

Copyright (C) 2021 by authors and Quest Journal of Management and Social Sciences.

This work is licensed under a Creative Commons Attribution-Non Commercial-No Derivatives 4.0 International License.

https://creativecommons.org/ licenses/by-nc-nd/4.0/

\section{Abstract}

Background: The concept of devolution has always presented significant controversy in African unitary states. It is often viewed with inherent suspicion and skepticism based on the lack of mutual trust between the people and the government. While proponents see it as a form of empowerment, resistant groups in society view the decentralization of government powers and responsibilities as a gateway secession. Despite the devolution agenda being a major component of local governance in the Zimbabwean Constitution of 2013, it would not be practically implemented until the new dispensation that rose into power in 2018 . However, the coming in of the COVID-19 pandemic has significantly marred the take-off of devolution implementation in Zimbabwe. Whilst COVID-19 cases continue to escalate on the globe, African countries continue to battle not only with the second wave of the pandemic but also with the new COVID-19 variants. Fragile economies have been left on the brink of collapse and other social and developmental issues left behind as Governments have had to play catch 22 in reprioritizing national budgets in response to the pandemic.

Objective: This study discusses the contemporary status of devolution in Zimbabwe to ascertain the extent of implementation; provide supportive legislation for devolution structures through recommendations; analyze devolution disbursements from 2019 before COVID-19 to date; assess the local authorities' initial requests versus the disbursements in 2019 and 2020.

Method: The researcher carried out a desk review and followed the principles of case study design by analyzing financial statements, reports and data coming in from the Councils and relevant Government ministries. The meaning was also derived by critically reviewing, organizing and interpreting related information from books and articles published in newspapers and journals.

Result: Despite Section 264(1) of the Constitution providing for devolution of power to the three tiers of the Government, there is no supporting legislature in place as yet to actualize this key element. The Government Budgetary Allocation of 5\% is not meeting local authority demands.

Conclusion: The onset of the COVID-19 pandemic in late 2019 reduced the pace of the devolution process because the funds were channeled to fight against the virus. If properly practiced, devolution may be one of the solutions to the development of the Zimbabwean economy since the devolution program is largely founded on the principle of empowering provincial government councils and Local Authorities to spearhead economic and social development projects in their areas by leveraging on local resources. It may also solve issues of corruption in many local councils in Zimbabwe by improving accountability mechanisms, especially where sub governments are permitted to progressively compete with each other to establish innovative ways of delivering public services efficiently and inexpensively.

Implications: The findings imply that the Government policies can affect the social and economic well-being of citizens, however, the COVID-19 pandemic has far outweighing impacts. Secondly, the coronavirus outbreak has proved how much the Government of Zimbabwe is illprepared to deal with a pandemic of this dimension. Policymakers should ensure that finances are set in the national budget for unseen events so as not to derail other Government projects.

Originality: This paper is original and not sent anywhere for publication.

Paper Types: Research Paper

Key Words: Devolution, Decentralisation, Constitution, COVID-19, Financial Resources

JEL Classification: G38, H72, H75 


\section{Introduction}

EZimbabwe's devolution agenda is largely founded on the principle of empowering provincial government councils and local authorities to spearhead economic and social development projects in their areas by leveraging local resources. Over the years Local Authorities have been biased towards the provision of basic municipal services such as water and sewer reticulation, waste management, etc. and not necessarily promotion of business and investment. Chapter 14, Section 264 of the 2013 Zimbabwean Constitution provides the administrative and legal pronunciation of the devolution framework whilst Section 5 of the same Constitution stipulates the 3 tiers of Government: National, Provincial/Metropolitan Councils and Local Authorities It goes on to describe and give powers and responsibilities to these structures, giving a concrete dimension of the devolution legal framework, how it would be implemented, and the expected outputs of the program. Section 301 of the same Constitution provides fiscal transfers to both Provincial and Local Governments. Section (2) also provides guidelines on the use of funds.

Governments that have advocated for the devolution trajectory claim that it yields, improved public accountability, environmental sustainability, and the empowerment of the poor and vulnerable groups (Anderson \& Ostrom, 2008). These positives can, however, only be realized into implementable actions if the said governments adequately allow for decentralization of the said powers efficiently without resorting to a lethargic and restrained implementation process.

Despite the inclusion of devolution in the Zimbabwean Constitution of 2013, the previous Government of the late, former President Robert Gabriel Mugabe did not expedite the establishment of the implementing structures that facilitated the initiation of devolution. However, following the appointment of President Emmerson Mnangagwa in the Second Republic, devolution has been a topical issue with the Head of State rallying behind it. According to the same Constitution, one of the major objectives of devolution is to transfer responsibilities and resources from the national governments to establish a sound financial base for each provincial and metropolitan council and local authority. The new dispensation has empowered the Ministry of Finance to release and set aside funds amounting to a total of 5\% of the national budget to the Ministry of Local Government to the agenda of devolution. The Ministry is then responsible for disbursing these funds to the 92 rural and urban local authorities in the country. However, the agenda has been derailed by the threat of the coronavirus pandemic leading to exponential death tolls across the globe and causing a serious menace to society and public health as a whole. Like a roving target, the virus has been able to mutate giving rise to more virulent forms creating challenges for the development of effective vaccines and antidotes. There has been the South African, the United Kingdom and recently the Brazilian variant of the virus. Fragile economies have been left on the brink of collapse and Governments have had to play catch 22 in reprioritizing national budgets in response to the pandemic.

This paper focuses on the analysis of the current position in terms of implementing devolution in this COVID-19 era, whether the 5\% allocation of the devolution funds was released, a brief look at the formula for distribution and its shortcomings within the wider context of the shortcomings of devolution, and finally providing recommendations for the way forward if devolution is to be fully realized in Zimbabwe.

Section II critically examines the related literature; Section III outlines the research methods adopted in this study. Section IV includes findings and, finally, Section V concludes the study.

\section{Review of Literature}

\section{The Zimbabwean Devolution Agenda - The New Dispensation}

Zimbabwe is a unitary, democratic and sovereign republic governed by a single power i.e., the Central Government is ultimately supreme. Section 264 of the Zimbabwean Constitution provides the 
devolution of the governmental powers and responsibilities to Provincial/Metropolitan Councils and Local Authorities. The constitutional provisions emphasize economic development and not political power that remains with the central government under the unitary state structure of the country.

Various authors have come up with the definition of devolution that described the transfer of power and responsibilities from the central government to sub-national authorities. Rondinelli, 1987:131 defines it, "as a form of decentralization of power from the central government to the local government, whereas Smith (1997) postulates that it is the transfer of responsibility for planning, management and resource raising and allocation from the central government and its agencies to (a) field units of central government ministries or agencies, (b) subordinate units or levels of government, (c) semiautonomous public authorities or corporations, (d) area-wide, regional or functional authorities, or (e) non-governmental private or voluntary organizations.

"Devolution is also viewed as an agent for revitalizing local governance by creating autonomous political subdivision, which has the authority and responsibility to execute local affairs, steer socioeconomic development whilst promoting citizens participation at the same time" (De Visser, 2001; Bussuyt, 2007). Rondinelli et al (1983:12) posit that 'ultimately decentralization is an ideological principle, associated with objectives of self-reliance, democratic decision-making, popular participation in government and accountability of public officials to citizens.'

The new dispensation's concept of Devolution is a considerable shift from the previous forms of local governance approaches which retained all executive powers for the Minister in charge of local government who presided overall issues and matters within local authorities. The Ministry of Local Government and Public Works, working within the framework provided by the Constitution and the vision set by the President, has since triggered key processes towards the realization of devolution which is considered an important medium to achieving national economic growth in the history of Zimbabwean local governance, the central government has always played a pivotal role in the day-today running of local authorities. However, for the first time in the history of local government, "citizens participation and empowerment are the major elements at the epicenter of the governance process in the new devolutionary discourse," (Mapuva, 2015). Accordingly, devolution, constitutional vision, political power, policy-making decisions, resource raising and distribution, as well as administrative and governance responsibilities are meant to be developed through three tiers of government (Moyo $\&$ Ncube, 2014).

In as much as devolution is key, politically, recipients of delegated political power, fiscal responsibilities and management of local resources are to remain subordinate and loyal to the central government. However, for the devolution trajectory to be successful there is a need for the Government to review socio-economic, political and legislative measures in place. Furthermore, it is necessary to create sound public financial management systems at both the metropolitan and local authority levels by giving financial support to decentralized entities. Section 301 of the Constitution of Zimbabwe provided for an allocation of Intergovernmental Fiscal Transfers (IGFT) from central government to provincial and local tiers of Government to support the devolution of governmental powers and responsibilities. This is further supported by Section 301 (3) of the Zimbabwean Constitution which further stipulates that not less than five percent of the national revenues raised in any financial year must be allocated to Provinces and Local Authorities.

\section{Historical antecedents of COVID-19}

LaiCC, ShihTP, KoWC, et al. (2019) posit that the world is under threat from a novel severe acute respiratory syndrome coronavirus-2 (SARS-CoV-2) which causes an infectious disease called coronavirus disease, (COVID-19. The highly contagious virus was first discovered in Wuhan City of China in 2019 and was then declared a global pandemic by the World Health Organization on March 11, 2020, (Chigiya-Mujeni,2019; Dutoit, 2020). Whilst COVID-19 has affected most countries like the 
United States of America, Spain, Italy, Germany, France, the United Kingdom, China, Iran, Turkey, it has hit some countries far harder than others and has recorded economic shocks three times worse than the financial crisis which happened in 2008. Different governments have come in with various plans and strategies to minimize the spread of infection through impositions of lockdowns, curfews, closing borders, quarantine and isolation of inbound citizens. Even though cases seem to be dwindling, the COVID-19 infections are still rising in about 56 countries. Globally there have been at least 114,206,000 reported infections and 2,636,000 reported deaths caused by the new coronavirus so far. Despite Africa having the lowest number of confirmed cases, it has become the most vulnerable continent where the COVID-19 spreading has had major socio-economic impacts, (Moore, Gelfeld, Okunogbe, et al., 2020). The first case of COVID-19 in Africa was recorded in Egypt on the 14th of February 2020, followed by Nigeria which reported its case on 27 November after an Italian patient flew to Nigeria from Italy (WHO, 2020). The Zimbabwean government declared the COVID 19 outbreak a national disaster following the death of one citizen and immediately launched a National Response Plan on 17th March 2020 to minimize and control the spread of the virus, (Chigiya-Mujeni, 2020). The COVID-19 has had a severe economic impact on the African economy but analysis of these implications in both public media and academic writing has mainly focused on global and macroeconomic impacts ignoring the effects on smaller economies. For instance, the first comprehensive report on COVID-19 from the Brookings Institution modeled the implications of the COVID-19 pandemic on macroeconomic outcomes and financial markets, (McKibben \& Fernando, 2019). Current studies do not even show the effects of the COVID-19 on government programs like devolution in countries like Zimbabwe which is still in the infantry stages of implementing devolution.

\section{The current status of Devolution in Zimbabwe: Where are we?}

There have been marked positives in terms of implementing devolution in Zimbabwe since the Government of the New Dispensation rose into power. The appointment of the current Minister of Local Government and Public Works, Cde July Moyo who has been the lead champion of devolution has been seen as a positive sign since his educational background, orientation, and experience are geared towards the public sector and local governance. The Government of Zimbabwe (GoZ) has also facilitated the continuous election and appointment processes of local councilors as these are key drivers of devolution at the local levels. Since public awareness and people conscientization is also one of the major drivers of devolution, the President of Zimbabwe has been seen and heard across media platforms actively addressing the issue of devolution and calling upon all stakeholders, private and public institutions to be active to this new philosophy of provincial economic development (The Daily News; 2015). Further, in line with the dictates of the Constitution (Amendment No 20 of 2013), His Excellency, the President, Cde E.D Mnangagwa, has underscored the need for the country to fully embrace devolution as a strategy to facilitate rapid economic growth. President Mnangagwa has frequently and publicly spoke on devolution, power generation, enforcing the notions of political will towards the process. The Ministry of Local Government has also set various indabas across the country to share and discuss the devolution issues.

The Ministry of Local Government, as the key ministry and lead agent in the rollout of the devolution agenda, has received a considerable overhaul in its structures to ensure smooth operationalization of devolution. Under the new structure, the titles of the District and Provincial Administrators have been changed to Provincial and District Development Coordinators. The posts were advertised in the Sunday Mail on 12 February 2019 and the job descriptions explicitly stated that these were new posts under the devolution agenda. Various posts such as the Director for Local Governance, Director for Economic Development, Director for Infrastructure, all reporting to the Provincial Development Coordinator have all been created under this new provincial devolution structure. 
Furthermore, the government has implemented the provisions of Section 301 (3) of the Zimbabwean Constitution which states, "Not less than five percent of the national revenues raised in any financial year must be allocated to the provinces and local authorities as their share in that year". Muchandenyika (2013) reiterated that inter-governmental transfers are an important aspect for a devolved system to work practically. In 2019, the Government committed to setting aside five percent of budget allocation for constituency-based development to local authorities. Under this devolution agenda, a national fiscal transfer system (or formula) was also developed with several variables to come up with an equitable distribution criterion. The Ministry of Finance makes use of this predetermined formula that takes into account:

- $\quad$ Population index - Population component based on the proportion of people in the province to the national population and the number of people in a given Local Authority to the provincial population in which the Local Authority is located (2012 Census National Report, adjusted by the annual growth rate of $1.1 \%$ ).

- $\quad$ Poverty Incidence Index - Poverty prevalence component based on the estimated number of people living in poverty per given Province and Local Authority (Zimbabwe Poverty Atlas 2015 Report).

- Unpaved Roads Index - Used to approximate infrastructure deficit. This is based on the proportion of unsurfaced roads per given Province and Local Authority to the National and/ or Provincial unsurfaced road network respectively (Roads Condition and Inventory Report 2017).

- Combined Weighted Index - This is a simple average of the above components, implying equal weighting of the indicators.

These factors are considered by the Ministry in ascertaining the level of distribution of funds to the various local authorities throughout the 10 provinces of Zimbabwe.

\section{Research Methods}

\section{Methodology}

A desk review approach of secondary data was employed to provide contemporary information regarding the status of devolution in Zimbabwe. The study analyzed the data from reports and financial statements from key government ministries involved with finance and devolution. The key concerns of the study were the ways different government agencies distributed the 5\% allocated funds; the ways the local authorities applied for it and they received and criteria they considered for release; and how the funds have been used. In the process of analysis, the challenges faced during devolution were broadly categorized in formal and informal resources based on the classification system of Leonardi, Nanetti and Putnam (1981). The paper also looked at the funds released and the way forward in terms of implementation of the devolution agenda through analysis of reports. The researcher implored case study analysis since it is an appropriate strategy to gain a deeper understanding of the context of the research and its processes (Saunders et al., 2007). Case studies are also important in that the researcher develops an in-depth analysis of a case, often a program, event, activity, process (Cresswell, 2018).

\section{Study Area}

This research focused on the 92 Local Authorities situated in the 10 Provinces of Zimbabwe comprising of the 30 Urban Local Authorities and 62 Rural Local Authorities. 


\section{Figure 1: Study Area}

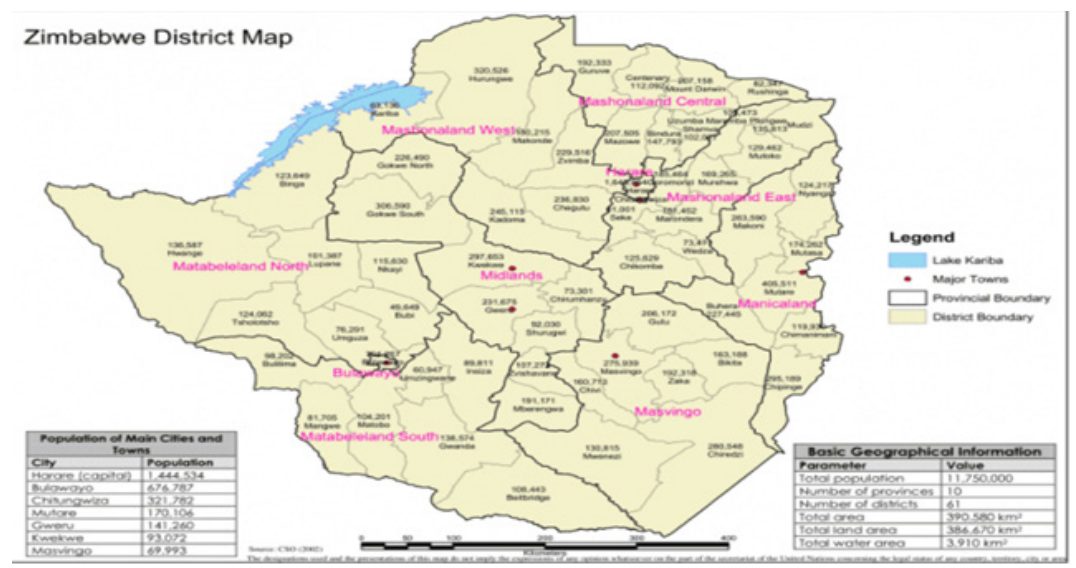

\section{Data Analysis and Results}

\section{Disbursement of Devolutionary Funding (2019 - 2020)}

Following the findings of the Ministry of Finance, through its matrix, approval to access funds from the provincial budget is based on local authorities' proposals to utilize the funds for projects under specific categories of development. These categories are water and sanitation, agriculture, health, education, social services, and infrastructural development. Assessment of the disbursement of funds for devolution in the 2019 and 2020 financial years points to the need for greater contextual savvy by policymakers and devolution practitioners if the processes of decentralization are to be successful. The assessment further reveals a challenge to the rigid formulaic system which does not immediately consider the inherent needs or competitive advantages of a province or local authority by limiting its range of potential projects to pursue. Further, the unforeseen and poorly addressed economic challenges of Zimbabwe, coupled with poor oversight, administration, and transparency, contributed significantly to the outcomes of the first year of practical devolution exercises under the new regime. Based on the data collected from the Ministry of Local Government, the following illustrations were developed to communicate the distribution of these funds across provincial lines.

Table 1: 2019 Distribution of devolution funds by Province

\begin{tabular}{|l|c|c|c|}
\hline \multicolumn{4}{|c|}{2019 PROVINCIAL DEVOLUTION FUNDS } \\
\hline \multicolumn{1}{|c|}{ Province } & Budget & Disbursements & Variance \\
\hline Manicaland Province & $92,189,900.00$ & $93,189,922.00$ & $-1,000,022.00$ \\
\hline Mashonaland Central Province & $73,089,464.00$ & $68,089,464.00$ & $5,000,000.00$ \\
\hline Mashonaland East Province & $64,860,000.00$ & $69,504,000.00$ & $-4,644,000.00$ \\
\hline Mashonaland West Province & $91,538,000.00$ & $96,538,000.00$ & $-5,000,000.00$ \\
\hline Matabeleland North Province & $41,627,000.00$ & $41,627,000.00$ & - \\
\hline Matabeleland South Province & $48,345,500.00$ & $48,345,500.00$ & - \\
\hline Midlands Province & $89,018,836.00$ & $89,018,836.00$ & - \\
\hline Masvingo Province & $80,017,000.00$ & $81,017,000.00$ & $-1,000,000.00$ \\
\hline Bulawayo Metropolitan Province & $30,134,300.00$ & $22,402,000.00$ & $7,732,300.00$ \\
\hline Harare Metropolitan Province & $\mathbf{6 1 1 , 8 0 4 , 0 0 0 . 0 0}$ & $\mathbf{6 8 4 , 9 6 2 , 7 2 2 . 0 0}$ & $\mathbf{- 7 3 , 1 5 8 , 7 2 2 . 0 0}$ \\
\hline TOTALS & $\mathbf{1 , 2 2 2 , 6 2 4 , 0 0 0 . 0 0}$ & $\mathbf{1 , 2 9 4 , 6 9 4 , 4 4 4 . 0 0}$ & $\mathbf{- 7 2 , 0 7 0 , 4 4 4 . 0 0}$ \\
\hline
\end{tabular}


Following the 2019 Mid-Year Budget and Review and Supplementary Budget, a total of ZWL \$703 million of the budget was allocated to provinces in 2019 by the Ministry of Finance (ZEPARU 2020). Following a further adjustment which raised funds for disbursement to ZWL \$1.2 billion, actual disbursement to rural and urban councils for the year 2019 was ultimately pegged around 1.29 billion dollars, representing an overrun of approximately ZWL \$600 million from the initial ZWL $\$ 703$ million. The reasons for these fluctuations stem from an unstable and unpredictable economic environment. The 2019 budget was initially prepared using the United States Dollar (USD) and the government subsequently issued Statutory Instrument 142 introducing the local currency which was initially pegged at par with the US dollar. The local currency would then experience variance due to inflation, resulting in the depreciation of the local currency. By December 2019, the ZWL Dollar was officially trading at 1:16 with the USD. Therefore, though the central government disbursed more than what was in the budget, the value of the funds got eroded by inflation due to the depreciation of the local currency. As a result, councils were incapacitated to achieve their devolution targets. Furthermore, since there has been no extensive monitoring or assessment of the movement of these funds, it is still yet to be determined if these funds were appropriately used for devolution-related projects.

Figure 2: 2019 Distribution of devolution funds by Province

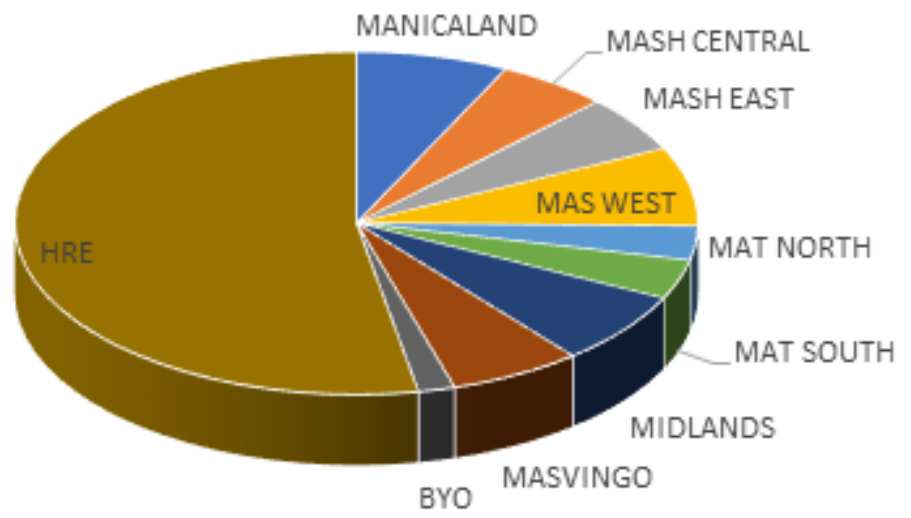

Further analysis of the 2019 disbursement data reveals that Harare Metropolitan province received approximately 53\% of adjusted devolution funds (Figure 1.1). Manicaland and Midlands Provinces received approximately $7 \%$ each, while Masvingo received $6 \%$.

For the 2020 fiscal year, Treasury allocated ZWL\$2.9 billion under Inter-Governmental Fiscal Transfer (IGFT) to local authorities.

Figure 3: Treasury Allocated

\begin{tabular}{|c|c|c|c|c|c|c|c|c|c|c|}
\hline & \multicolumn{2}{|c|}{ MANICALAN \% } & \multicolumn{2}{|c|}{ MASH CENTRAL } & \multicolumn{2}{|l|}{ MASH EAST } & MASH WEST & \multicolumn{3}{|c|}{ MAT NORTH } \\
\hline Water, Sanitation and $\mathrm{H}_{\mathrm{f}}$ & $103,000,000.00$ & $30 \%$ & $58,000,000.00$ & $26 \%$ & $78,160,500.00$ & $28 \%$ & $116,370,000,00$ & $32 \%$ & $33,116,900.00$ & $21 \%$ \\
\hline Roads and Sureer Lighting & $87,219,554,00$ & $25 \%$ & $74,000,000,00$ & $33 \%$ & $72,000,000,00$ & $26 \%$ & $90,000,000,00$ & $25 \%$ & $43,000,000,00$ & $28 \%$ \\
\hline Social Services & $12,000,000,00$ & $3 \%$ & $4,925,000,00$ & $26 \%$ & $6,537,500,00$ & $2 \%$ & $30,000,000,00$ & $8 \%$ & $2,860,000,00$ & $2 \%$ \\
\hline Heath & $15,000,000,00$ & 48 & $10,040,000.00$ & $4 \%$ & $24,000,000,00$ & $9 \%$ & $17,000,000,00$ & $5 \%$ & $12,108,100.00$ & $8 \%$ \\
\hline Education & $27,000,000,00$ & $8 \%$ & $23,287,000,00$ & $10 \%$ & $29,000,000,00$ & $10 \%$ & $25,000,000,00$ & 786 & $6,900,000,00$ & $4 \%$ \\
\hline Agriculure & $11,000,000,00$ & $3 \%$ & $2,200,000,00$ & $1 \%$ & $2,800,000,00$ & $1 \%$ & & $0 \%$ & & $0 \%$ \\
\hline Governance and Adming & $93,069,000,00$ & $27 \%$ & $54,000,000.00$ & $24 \%$ & $69,582,000,00$ & $25 \%$ & $82,445,000.00$ & $23 \%$ & $57,782,000,00$ & $37 \%$ \\
\hline & $348,288,554,00$ & $100 \%$ & $226,452,000,00$ & $100 \%$ & 282.080 .000 .00 & $100 \%$ & $360,815,000,00$ & $100 \%$ & $155,767,000.00$ & $100 \%$ \\
\hline
\end{tabular}


Chigiya-Mujeni: Financing devolution in a COVID-19 environment. The status of devolution in Zimbabwe.

\begin{tabular}{|c|c|c|c|c|c|c|c|c|c|c|c|c|}
\hline & MAT SOUTH & $\%$ & MIDLANDS & $\%$ & MASVINGO & $\%$ & HARARE & $\%$ & BYO & & GRAND TOTAL & TOTAL \% \\
\hline Water, Sanitation and H) & $84,209,35200$ & $31 \%$ & $107,389,000.00$ & $30 \%$ & $67,704,000.00$ & $22 \%$ & $188,000,000,00$ & $36 \%$ & $45,000,000,00$ & $48 \%$ & $880,949,752.00$ & $30 \%$ \\
\hline Roads and Sueet Lighting & $78,667,831.00$ & $29 \%$ & $79,442,735,00$ & $22 \%$ & $52,208,500.00$ & $17 \%$ & $130,000,000,00$ & $25 \%$ & $12,000,000,00$ & 13\% & $718,538,620,00$ & $25 \%$ \\
\hline Socal Services & $15,172,215,00$ & $6 \%$ & $6,080,500,00$ & $2 \%$ & $12,250,000,00$ & $4 \%$ & $3,040,000,00$ & $1 \%$ & $2,060,000,00$ & $2 \%$ & $94,925,215,00$ & $3 \%$ \\
\hline Heath & $22,000,500,00$ & $8 \%$ & $52,500,400.00$ & $15 \%$ & $62,469,000,00$ & $20 \%$ & $105,571,000.00$ & $20 \%$ & $7,000,000,00$ & $7 \%$ & $327,689,000,00$ & $11 \%$ \\
\hline Education & $15,000,000,00$ & $5 \%$ & $35,500,365.00$ & $10 \%$ & $49,626,000,00$ & $16 \%$ & $24,603,762.00$ & $5 \%$ & & $0 \%$ & $235,917,127,00$ & $8 \%$ \\
\hline Agriculure & & $0 \%$ & & $0 \%$ & $2,036,500,00$ & $1 \%$ & & $0 \%$ & & $0 \%$ & $18,036,500.00$ & $1 \%$ \\
\hline \multirow[t]{2}{*}{ Govemance and Admins } & $60,347,750,00$ & $22 \%$ & $76,164,000.00$ & $21 \%$ & $62,784,000,00$ & $20 \%$ & $71,155,000,00$ & $14 \%$ & $28,615,000,00$ & $30 \%$ & $655,943,750,00$ & $22 \%$ \\
\hline & $275,397,648,00$ & $100 \%$ & $357,077,000,00$ & $100 \%$ & $309,078,000,00$ & $100 \%$ & $522,369,76200$ & $100 \%$ & $94,675,000,00$ & $100 \%$ & $2,931,999,964,00$ & $100 \%$ \\
\hline
\end{tabular}

\section{Devolution and COVID-19}

The Covid-19 catastrophe has extremely uncovered the issues that underpin local relations within Southern Africa. In Zimbabwe, where devolution is still in its teething stages and developing in fits and starts, the pandemic has thrown into even sharper relief the long-standing tensions between the Central and Local Government. History of dictatorial nature and over-centralization of power has tarnished the history of Zimbabwe since independence. This is not, however, unique in African states only but even in the developed world where the UK is known as one of the most centralized countries in the developed world and the root cause of growing regional inequalities across the country (Raikes, Giovannini \& Getzel, 2019). The Covid-19 panfemic has taken the world by storm and the challenges of concentration of power has exposed governments failures in upholding the values of devolution as governments all over the world instinctively entered into, "top-down command and control' mode centralizing even further decision making in the face of the stark regional differences in the spread and impact of the Covid-19, without making any use of, and often snubbing, devolved and local government institutions" (Giovannini, 2020).

In the year 2020 local authorities were allocated a total of 2.932 billion but only managed to utilize 1.044 billion that was released by the government. This represents $36 \%$ of the allocated amount.

Table 2: Allocated Budget

\begin{tabular}{|l|r|r|r|r|}
\multicolumn{1}{l}{ Budget } & \multicolumn{1}{l}{ Actual } & \multicolumn{1}{l|}{ Variance } & \multicolumn{1}{c|}{ Variance } \\
\hline Midlands Province & $357,077,000.00$ & $104,253,054.00$ & $252,823,946.00$ & $29 \%$ \\
\hline Harare Metroplotan & $522,369,762.00$ & $471,456,233.00$ & $50,913,529.00$ & $90 \%$ \\
\hline Bulawayo Metropolitan & $94,675,000.00$ & $43,800,000.00$ & $50,875,000.00$ & $46 \%$ \\
\hline Manicaland Province & $348,288,554.00$ & $79,635,243.00$ & $268,653,311.00$ & $23 \%$ \\
\hline Mashonaland Central & $226,452,000.00$ & $60,347,800.00$ & $166,104,200.00$ & $27 \%$ \\
\hline Mash East Provincial & $282,080,000.00$ & $69,331,984.00$ & $212,748,016.00$ & $25 \%$ \\
\hline Mashonaland West & $360,815,000.00$ & $87,307,842.00$ & $273,507,158.00$ & $24 \%$ \\
\hline Masvingo Provincial & $309,078,000.00$ & $40,251,500.00$ & $268,826,500.00$ & $13 \%$ \\
\hline Mat North Province & $155,767,000.00$ & $33,689,724.00$ & $122,077,276.00$ & $22 \%$ \\
\hline Mat South Provincial & $275,397,684.00$ & $53,937,500.00$ & $221,460,184.00$ & $20 \%$ \\
\hline & $\mathbf{2 , 9 3 2 , 0 0 0 , 0 0 0 . 0 0}$ & $1,044,010,880.00$ & $1,887,989,120.00$ & $36 \%$ \\
\hline
\end{tabular}

The reallocation of funds by the treasury was done arbitrarily without consulting the local authorities. Whilst treasury continues to boast of a budget surplus, local authorities have been incapacitated due to the inadequate funds that were released versus what was in the actual 2020 budget. At the present, the devolution agenda is developing lethargy. Councils had in the 2020 budget earmarked various workshops to articulate the devolution agenda and bring awareness to the citizenry under the Governance and Administration vote but all these have been suspended due to the lockdown and 
restrictive measures in place. The Zimbabwean economy is largely informal, (employing more than $80 \%$ of the population), as a result of the lockdown people have not been able to go about their daily activities. As a result, residents have not been able to pay for their council bills further compounding on Local Authorities' ability to deliver services e.g., Harare City council currently has debtors above 4 billion dollars. Some councils have suggested that they charge for services in US dollars or link these charges to the ruling exchange rate but their plea like in the old days requires government consent.

The appalling conditions of the health system, testing and contact tracing, administration and distribution of Personnel Protective Equipment (PPE), non-release of funds to local authorities, closure of some hospitals due to lack of proper Covid-19 equipment and PPEs for health personnel, only show that local authorities in Zimbabwe are poorly supported in terms of finance and control. The 5\% release of funds by the Government to Local Authorities was extremely poor in 2020 and this negatively impacted Council's performance and service delivery in their communities. The underfunding of the local health systems was exposed at the onset of the pandemic as most local authorities' health facilities did not have ventilators or oxygen. The government response has been to blame local authorities for poor service delivery and take over the running of the institutions. Considering the difficult financial position of local authorities in Zimbabwe, and with the rumor of fake data on infection rates, there is a real risk that Zimbabwe might be brewing yet another Covid-19 shock. Devolution of finances from the central to local authorities is happening at a snail pace and it is the local communities that are now bearing the brunt of the Covid-19 pandemic.

It is also necessary for the local leadership to be at the forefront in terms of abiding by the dictates of devolution and, if the government is serious about its commitment to 'level up' the country, it should re-invest the local state with the resources, power and trust it needs and deserves (Giovannini,2020). In Zimbabwe, despite the resident ministers being sworn into power, they cannot do much without any financial disposition. The President has also sworn in to support the processes of devolution but again without fully giving the resident ministers the funds to do projects in their communities and support their people, it might as well be talk without action. There is a need for the government to take a holistic approach and support local authorities as to the third tier of the government and give them necessary powers and instruments so that they effectively provide the necessary services in their areas.

\section{Figure 4: 2020 Provincial budget allocation versus actual expenditure} 2020 PROVINCIAL BUDGET ALLOCATIONS VERSUS ATCUAL EXPENDITURE

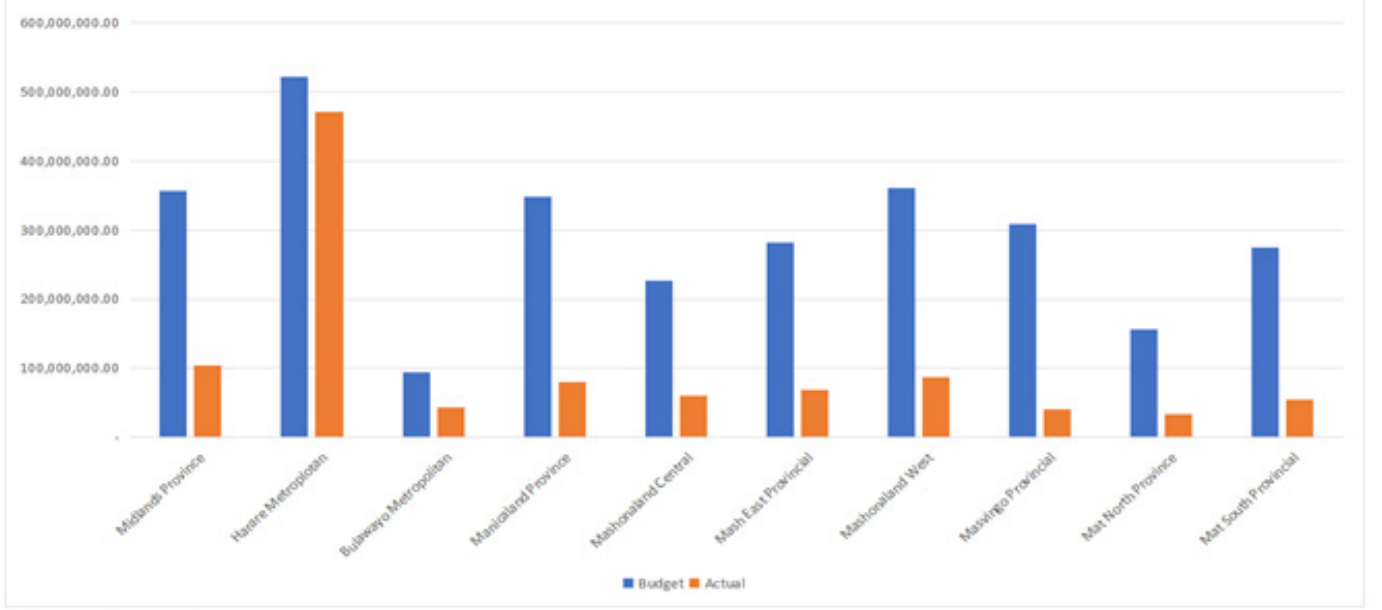




\section{Devolution Shortfalls}

Despite all commendable efforts and measures exercised by the government to kick-start the devolution processes, significant efforts are still required. Bogdanor (1999) equates the devolution journey to a mystery tour in which ordinary citizens are unaware and the final destination is obscured and unknown. As previously mentioned, legal, administrative, political and socio-economic measures were critical and integral for turning symbolic statutory pronunciations of the devolution trajectory into solid and tangible implementation dimensions. Nonetheless, the process of traversing devolution is muddled with uncertainties and challenges that have disrupted Zimbabweans from fully operationalizing devolution since its inception. These challenges can be broadly divided into two categories, namely, "formal resources (laws, rules, and money) and informal resources (technical expertise, public opinion and the politics of political parties"(Leonardi, Nanetti \& Putnam, 1981).

Although Section 264(1) of the Constitution indeed provides for devolution of power and responsibility to provincial, metropolitans and local authorities, there is no supporting legislature in place as yet to actualize this key element. This does not only make the Section cosmetic but implementation difficult. Legally, the Constitution of Zimbabwe enables the establishment of provincial councils whose mandate is to champion developmental programs at provincial levels. The said councils are to be under the stewardship of chairpersons and served by a dedicated secretariat. Six years following initial ratification, the councils in question are yet to be operationalized. Despite the government of the new dispensation being at the forefront of the devolution agenda, there has been minimal movement with regards to setting up the said provincial councils.

It is noteworthy that the current government has appointed a host of Provincial Ministers formally known as governors. However, the appointment of these ministers has been seen as retrogressive and a detriment to the devolution trajectory. Moyo and Ncube (2014) view the action of appointment of Provincial Ministers of State as an effort to underplay the devolution process since they report to the central government. According to Madzenge (2012), such a situation provides for a continuation of the old system where power is centralized within the central government. This kind of situation portrays a picture where there is no political willpower in the leadership to change the modus operandi. Proponents of this view fear that the appointment of these ministers will create leadership hierarchy challenges in the provinces since the provinces will have provincial councils led by Provincial Council Chairpersons. This leadership crisis may result in considerable amounts of confusion as the positions of the political and administrative head of a province become blurred. Accordingly, this opaque leadership structure will have direct implications on local policymaking, service delivery and local development. This delay in correcting the legal frameworks of devolution guidance will bring about disillusions in terms of separation of duties and roles of these two offices - the Provincial Ministry and the Provincial Council Chairperson.

There is marked debate revolving around the control of provincial councils especially in Metropolitan areas where the President appointed the Minister of State for Provincial Affairs and Devolution whilst the electorate has a representative in the form of the Council Chairperson or Mayor. There are bound to be ideological clashes in leadership should two different parties have a seat at the apex of the council. The apparent lack of commitment in amending legislative processes is seen as a devolution caveat that allows one to begin to question the substance, breadth and depth of Zimbabwe's devolution legal framework.

The hierarchical nature or bureaucratic form of government systems and structures tend to be a hindrance to the effective decentralization of government powers. There is a propensity for confusion in reporting structures and duplication of duties since there are various offices interested and mandated to deal with devolution issues. Who has the final say and where are the reports of devolution to be complied, sent, and evaluated? Is it the Minister of Local Government, the Provincial Chairperson, the 
resident Provincial Minister, or the Office of the President and Cabinet (OPC) who has been recently mandated to deal with policy issues surrounding devolution?

Morgan (2001) postulates, "for devolution to achieve territorial justice, allocation of public expenditure to sub-governments should be based on a need-based assessment by region and not by population". From the above, the Ministry of Finance's formula-based distribution of funds to local authorities was not need-based. Each council had to submit a plan, which had to be approved by the Ministry of Local Government, of their budget-making decisions as to where and how the funds will be utilized. "Each authority had to come up with a priority list of capital projects that benefit the generality of the citizenry in the following service areas, schools and clinics, roads, plant and equipment, water, sewer and solid waste management, electricity and any other capital activities that may be deemed necessary for service provision" Sikha (2020).

The provision of basic needs such as water and sanitation, health, education, and infrastructure are some of the constitutional obligations of every government. According to Section 301 of the Constitution of Zimbabwe, devolution funds were meant to address issues of marginalization in areas of basic service delivery such as education, health, roads, water and sanitation, social amenities, amongst others. The granting of a minimum of $5 \%$ to provincial offices to satisfy the constitutional requirement demonstrates the insincerity on the part of the central government in giving the provincial and local authority capacity to deliver a decent service to its communities. What is clear is that the constitution sets a minimum requirement, not a ceiling, meaning that the Ministry of Finance can go beyond the 5\%. Compared to other countries in Africa like South Africa which has 95\% expenses of the provincial councils being funded from the central government, the 5\% allocation personifies lack of willpower by the GoZ. Whilst the figures provided to local authorities appear to be substantial, if one interrogates the rate of inflation in Zimbabwe and the needs of local authorities the figures fall short of their requirements, a case in point being the Harare City Council. According to the Harare City Council Mayor, Hebert Gomba, they require 9 million dollars for water treatment chemicals per month. Converted to the local currency at the official rate of USD 1 to $\$ 25 \mathrm{rtgs}$ (at time of publication) the monthly requirement becomes 225 million dollars and the annual allocation of \$234 million becomes insignificant. The City of Harare is also riddled with numerous challenges that require funding amongst them the replacing of their aging water pipe network that is resulting in $60 \%$ of their treated water being lost and as a result not being billed.

While it is valid that service delivery in both the urban and local authorities has been poor due to a variety of reasons, an unmistakable cause of this is the inability of local authorities and the central government to coordinate their governance and developmental efforts, resulting in an unproductive blame-game that affects citizens. However, by providing such a meager percentage to the provincial and local authorities hinders their capacity to develop key services which also feed into the local and national focus, the central government is setting them (and themselves) up for perpetual failure. Unfortunately, this state of affairs has always created a polarisation in Zimbabwean politics which further diverts attention from the central issues. Citizens have had to turn to the courts to enforce their rights on some of the basics such as water and health. A case in point is the city of Mutare Residence Association who recently won a High court judgment enforcing the Mutare City Council to provide water to its residents.

In the 2020 budget, provinces were allocated various amounts which they intended to apply to various plans. However, 29\% percentage of the budget was spent on water, sanitation and hygiene but the quality of the service still fell short of expectations. The challenges ranged from the unavailability of forex to import the chemicals, dam levels that have fallen below expected levels that make it impossible to provide sufficient drinking water, and old water pipe network that results in massive leaking. Population and settlements have also been growing at a faster rate than the requisite infrastructure being built. There is, therefore, a need for serious discussion on how to address this deficit and how 
new infrastructure can be funded. Most plans to address these challenges are already in existence. What is left is to address the funding gap. The importation of chemicals needs to be investigated with a view of coordinating this as this might reduce the import bill. Previously most of the chemicals were manufactured locally, an effort has to be made to resuscitate these companies that used to manufacture them as this has the potential to lower the import bill. This work needs provinces and central government to work and coordinate with each other.

A total of $26 \%$ of the 2020 budget allocation has been earmarked for road rehabilitation. The state of the road network in the whole country remains poor. The state of roads is an important aspect of the development agenda as this promotes economic activities, linkages and connectivity. Years of neglect and the effects of natural hazards such as cyclones have left most roads in a poor state needing rehabilitation. New settlements that have been set up such as stadia, community centers, recreation parks require the necessary social service. A paltry 3\% was set aside towards social services in the 2020 budget. A private partnership with local authorities can help accelerate the development of new settlements and the construction of facilities such as stadia. Accordingly, health and education are universal rights and it is the responsibility of the government to ensure that they are available to citizens making sure that they do not need to travel a long distance to go to school or to access health services. Clinics and schools must be functional and fully equipped so that citizens can benefit. Health and education were each allocated $9 \%$ and $8 \%$ respectively.

In the total devolution budget, only $1 \%$ was allocated for agriculture yet the Zimbabwean economy has always been agro-based and all the provinces have always had a competitive advantage be it animal husbandry, crop farming, horticulture or fruit production. More needs to be done in agriculture to ensure farmers are well prepared against the adverse effects of climate change. Moyo and Ncube (2014) postulate the financing architecture of the devolved system of governance should be well thought out. They argue that a non-transparent, fragile public expenditure allocation system is not transparent, accountable and does not equitably distribute resources and may cripple the capacity of provincial governments to control, formulate and implement policies within their localities. It is yet to be seen whether the combined weighted index used in the equitable allocation of the financial resources comprising the population of an area, poverty prevalence, and infrastructure index will work in Zimbabwe. Currently, there is no proper monitoring and evaluation mechanism put in place by the government to monitor the use of these devolution funds by the councils. Notwithstanding the Ministry of Local Government has written a circular for funds acquittal in May 2019; less than 1\% of the councils submitted their reports by the end of 2020. It was also difficult for the Ministry to conduct evaluations since there was no operational budget for devolution evaluation set aside in the national budget. It was also against the constitutional arrangements for the Councils to set aside funds from the devolution budget for monitoring purposes.

The financial advisory section in the Ministry of Local Government completed only one monitoring exercise in December despite having sent the total yearly allocations to the councils. This is tantamount to abuse by local authorities since they are fully aware that the parent Ministry does not come in to monitor the projects. The financial advisory section was not well resourced and was lacking in terms of material resources. They had no vehicle, no laptop nor a functional printer to exercise their duties. Given that both the formal and informal resources imply a smooth transition of the devolution process, due care and attention need to be taken to ensure these are kept in check. Currently, capacity building on the efficient and effective running of devolution has been lacking for staff in the local authorities. Despite devolution funds having been disbursed within the Ministry of Local Government Finance Section, there has been no additional staff to cater for this added job responsibility. This seems to increase some form of a burden on the already short-staffed department thus compromising the attention paid to devolution efforts. Recruitment and training of staff with relevant qualifications to deal with devolution issues should be expedited. 


\section{Conclusion and Recommendations}

It is a fact that the devolution trajectory has taken off in Zimbabwe despite a plethora of issues slowing down the process. Due to the onset of the Covid-19 pandemic in late 2019, there has been a marked reduction in the pace of the devolution process with funds that were earmarked for devolution being channelled towards the fight against the virus. If properly practiced, devolution may be one of the solutions to the development of the Zimbabwean economy. It may also solve issues of corruption in many local councils in Zimbabwe by improving accountability mechanisms, especially where sub governments are permitted to progressively compete with each other to establish innovative ways of delivering public services efficiently and less costly. Furthermore, if properly implemented, devolution may promote local development since communities will be competing against each other, therefore, fostering local patriotism. A concerted effort from the state and local governments is essential and must remain persistent with the devolution agenda by continuing to establish strong governance mechanisms and ensuring promised resources meant for local authorities are delivered efficiently. Besides political will, there has to be buy-in from the citizens who should trust the position of the government and the benefits of devolution. Lastly, it is prudent for the country to have a road map of the devolution agenda and a barometer of measuring the success of its implementation.

Devolution in Zimbabwe is seen as a precondition for Local Economic Development and the attaining of an upper-middle-income national status by 2030 that is leveraged on the creation of decent jobs and improved quality of life. Morgan (2001) proffers, "devolution delivers economic dividends when it permits provincial governments to design and deliver developmental policies that respond to the needs and interests of provincial citizens". However, for an effective devolution process to kick off certain conditions are to be met and recommendations are made in this paper. Both the formal and nonformal resources are a sine quo non for an efficient devolution process The Government of Zimbabwe should act swiftly to align and harmonize existing legislation and bureaucratic structures in the new constitution. The necessary statutes that are required to operationalize the devolution agenda must be expedited to make sure that provincial councils start operating.

An effective provincial structure should first be put in place to ensure a smooth running of this process. A clear demarcation on separation of power between the three tiers of government should be outlined in line with this. There is, thus, the need for the government to clarify the roles of the two offices of the provincial minister of state and the provincial council chairperson to avoid further disillusionment and support the processes of decentralization. The reporting structure of the civil service at the ward level (youth officers, agriculture extension officers), district, and provincial levels need to be clear to avoid duplication of duties. Furthermore, there is a need for role clarification and realignment of the roles of the central government, provinces and local authorities. Some of the roles, such as the building of infrastructure like dams for sources of drinking water, need to be explored as they will provide an impetus for solving the water problems.

Morgan (2006) posited that devolution would treat unequal people as equal thus defeating the notion of equality or territorial justice. Therefore, to ensure equity in distribution and disbursements of funds Morgan (2001) postulates that the solution would be to, "proceed on the basis of the dictum that, it is people, not places which are poor". A transparent and equal public expenditure allocation system across provincial governments should, therefore, be devised for nationally derived policies with different provincial governments funding locally derived policy choices from revenue raised locally. He also reiterated that the absence of legislation that gives life to provincial and metropolitan councils makes the budgetary process undemocratic leading to a perpetuation of the old system which forces the local authorities to rely on whatever the Ministry of Finance deems sufficient. It is only prudent to have a budgetary process that allows provinces to assess their needs and requirements and forward these to the central government for funding. Apart from the central government meeting the minimum threshold 
of the $5 \%$ allocation of revenue to provinces, it is necessary also to look at what the provincial needs are and increase the allocation so that the citizenry gets a decent service from the government. There is also a need to review the whole budgetary process so that the citizenry enjoys the fruits of devolution as opposed to the central government meeting the minimum constitutional requirement of $5 \%$.

The government should also set aside funds specifically meant to cushion the public against public health disasters like the Covid-19 so as not to derail other planned programs like devolution. The Civil Protection Department in the Ministry of Local Government should be financially capacitated to enable it to achieve its organizational mandate of preparing for and protecting citizens against disasters. The local governments have an informational or comparative advantage because of their proximity to the needs of people (Moyo \& Ncube, 2014; Bardhan, 2002). The imperative to politically account to regional or provincial citizens renders it prudent for devolved government representatives to use local knowledge and local resources to improve the socio-economic conditions of locals. Provinces also need to identify their competitive advantage or natural endowments so that they can maximize their potential. Other provinces are rich in tourist attractions and fauna, others are endowed with mineral resources and those with potential for agriculture need to examine how they can attract investment and be able to bring development to their communities. An example would be coal mines in Hwange being used to process iron ore in Kwekwe, and solar projects in Lupane producing electricity to be fed into the national grid. The issue of both the road and railway networks would need to be rehabilitated so that the movement of both people and goods is enhanced. It is prudent that the provincial team led by the Provincial Development Coordinator create synergies and use a bottom-up approach to consult various groups within their province to come up with provincial economic development plans for the benefit of their people. Since these are government officials their salaries should be pegged against their performance. Provincial heads also need to identify other means like smart partnerships to augment their revenue and not solely rely on the central government for funding.

The issue of accountability is of paramount importance in a devolved state. Strong institutions that promote transparency and can identify corruption are needed for devolution to be successful. According to the Auditor General, most local authorities fail to produce audited accounts timeously and this has an effect of undermining public confidence in the manner that councils will be conducting their business. Capacity building in terms of policy formulation and implementation of technical expertise becomes of paramount importance to staff in all provincial and metropolitan councils. In the same light, institutions of democracy and mechanisms of political accountability would have to be equally strengthened. Furthermore, a culture of entrepreneurial acumen and business savvy must be inculcated in local authorities to promote more business-friendly environments for investors in line with set developmental targets. The resultant competition will also fuel local councils to outperform their counterparts for the betterment of citizens in their communities.

In addition, there should be continued supervision from the central government to ensure that the practice of devolution does not mutate into tribalism or regionalism ensuring that all citizens regardless of ethnic and linguistic identities have equal opportunities to enjoy economic growth anywhere they want nationally. In this regard, therefore, local government-based policies ought to reflect the broader national economic and socio-political policies to uphold the national unity and peace pledge in the constitution and safeguard against tribalism. Leonardi, Nanetti and Putnam (1981) further argue that it is crucial to building strong cooperation with civic society and several regional interest groups as they are poised to greatly assist the devolution processes. Marinetto M (2001) points out that the role of civil society is mainly to advocate for the new dispensation. Advocacy and publicity shape the devolution discourse in any country with Zimbabwe being one such state. It helps in enlightening citizens on the asymmetrical characteristic of policy transfer or transfer of power from top to bottom. This would ensure that the process of devolution gets achieved on an incremental trajectory. 


\section{Conflict of Interest}

Author(s) declares no conflict of interest while preparing this paper.

\section{References}

Bardhan P. (2002). Decentralization of governance and development. The Journal of Economic Perspectives. 16(4).

Bogdanor V. (2002). Devolution: Decentralisation or disintegration (1999). The Political Quarterly. 70(2).

Bonnet F, Vanek J, \& Chen M. (2019). Women and men in the informal economy: A statistical picture. Manchester: Women in Informal Employment: Globalizing and Organizing (WIEGO); 2019. Google Scholar

Constitution of Zimbabwe (2013).

Covid-19 cases top 10,000 in Africa. [Cited 2020 Apr 18]. Available at: https://www.afro.who.int/news/covid-19cases-top-10-000-africa [Google Scholar],10 NCDC

Crawford, G. (2009). Making democracy a reality? The politics of decentralisation and the limits to local democracy in Ghana. Journal of Contemporary African Studies.27(1).

De Visser, J, Steytler, N. \& Machingauta, N (eds.). (2010). Local government reform in Zimbabwe: A policy dialogue. Cape Town: Creda Communications.

Du Toit A. Outbreak of a novel coronavirus. Nat Rev Microbiol. 2020; 18:123. Doi: 10.1038/s41579-020-0332-0. [Google Scholar].

First case of coronavirus disease confirmed in Nigeria. [Cited 2020 Mar 11]. Available at: https://ncdc.gov.ng/ news/227/first-case-of-corona-virus-disease-confirmed-in-nigeria [Google Scholar].

Giovannini, A. (2020). Covid-19 and English devolution. Political Insight. 11(3), p. 40.

Leonardi, R, Nanetti, RY \& Putnam, RD. (1981). Devolution as a political process: The case of Italy. Publius: The Journal of Federalism.11(1).

Mapuva J, (2015). The controversies of devolution in Zimbabwe. Vol. 3(5), pp. 183-192.

McIntyre, D., Obse, AG., Barasa EW. \& Ataguba JE. (2018). Challenges in financing universal health coverage in sub-Saharan Africa. Oxford Res Encyclop Econ Financ. 2018(5):1-80.

Marinetto, M. (2001). The settlement and process of devolution: Territorial politics and governance under the Welsh assembly. Political Studies. 49(2).

McKibbin, W., Fernando, R. (2020). The global macroeconomic impacts of Covid-19: Seven scenarios. Washington DC: The Brookings Institution. Google Scholar

Moore, M., Gelfeld, B., \& Okunogbe A. (2017). Identifying future disease hot spots: Infectious disease vulnerability Index. Rand Health Q. 2017; 6(5). [Cited 2020 Mar 8]. Available at: https://www.ncbi.nlm.nih.gov/pmc/ articles/PMC5568150/ [Google Scholar].

Morgan, K. (2001). The new territorial politics: Rivalry and justice in post-devolution Britain. Regional Studies. $35(4)$.

Morgan, K. (2006). Devolution and development: Territorial justice and the north-south divide. Publius: The Journal of Federalism. 36(1).

Moyo, P. (2013). The devolution of power debate and the Zimbabwe national project. In Ndlovu-Gatsheni SJ \& Ndhlovu F Nationalism and national projects in Southern Africa: New critical reflections. Pretoria: Africa Institute of South Africa.

Moyo, P \& Ncube C. (2014). Devolution of power in Zimbabwe's new constitutional order: Opportunities and potential constraints, Law Democracy and Development. Volume 18 4907. http://dx.doi.org/10.4314/ldd. v18i1.

O'Hare B. Weak health systems and Ebola. Lancet Global Health. 2015; 3(2): e71-e7272.

Raikes, Giovannini \& Getzel. (2019). https://www.ippr.org/research/publications/state-of-the-north-2019'

Rondinelli, D.A. (1981). Government decentralization in comparative perspective: Theory and practice in developing countries. In International Review of Administrative Sciences. 47(2). 
Rondinelli, D. A., McCullough, J. S. \& Johnson, R. W. (1989). Analyzing decentralization policies in developing countries: A political-economy framework. In Development and Change, 20, 57-87.

Rondinelli, DA \& Nellis, J R. (1986). Assessing decentralization policies in developing countries: The case for cautious optimism. Development Policy Review. 4(1).

Smith. (1997). The decentralization of health care in developing countries: Organisational options. In Public Administration and Development. 17 (4).

The epidemic and the challenges. (2020). International Journal Antimicrob Agents. 55. Doi: 10.1016/j. ijantimicag.2020.105924. [Google Scholar]

WHO announces Covid-19 outbreak a pandemic Europe: World Health Organization, 2020 [cited 2020 Apr 18]. Available at: http://www.euro.who.int/en/health-topics/health-emergencies/coronavirus-covid-19/news/ news/2020/3/who-announces-covid-19-outbreak-a-pandemic [Google Scholar].

ZEPARU. (2020). Towards successful implementation of devolution in Zimbabwe. Zimbabwe Economic Policy and Research Unit

Parker, C. (2020). World vs. virus podcast: An economist explains what Covid-19 has done to the global economy. The World Economic Forum. Available at: https://www.weforum.org/agenda/2020/09/an-economistexplains-what-covid-19-has-done-to-the-global-economy/ 